\title{
Ownership of Space Objects
}

\section{Olexander Svitlychnyy}

\author{
Doctor of Law, Associate Professor, \\ National University of Life and Environmental Sciences of Ukraine \\ (Kyiv, Ukraine) \\ E-mail: a.svetlichnyj@ukr.net \\ https://orcid.org/0000-0003-0485-3804
}

The article is devoted to the study of the concept of «space objects» and their legal nature. The situation arising in international space law in connection with the adoption by the United States and Luxembourg of legislative acts aimed at the legalization, extraction, use and appropriation of space resources by private companies is analyzed. The legal acts, basic scientific opinions and legal positions of lawyers concerning the activity of different states in the space industry, the activities of the Committee on the Peaceful Uses of Outer Space and its Legal Subcommittee have been analyzed.

It is concluded that today the basic acts of international space law are lagging behind the development of scientific and technological progress, and the relevant UN structures are not able to solve all the pressing problems of space activity. It is proposed to adopt a number of agreed normative legal acts of international space law and to create a new organization on issues of space activities.

Keywords: ownership, space objects, natural resources, international space law, regulations, organization

\section{Право власності на космічні обєкти}

\section{Світличний, Олександр Петрович}

\author{
Доктор юридичних наук, доцент, \\ Національний університет біоресурсів і природокористування України
}

(Київ, Україна)

Стаття присвячена дослідженню поняття «космічні об'єкти» та їх правової природи. Аналізується ситуації, що виникла в міжнародному космічному праві у зв'язку з прийняттям США та Люксембургом законодавчих актів, метою яких є легалізація, видобуток, використання та присвоєння космічних ресурсів приватними компаніями. Проаналізовано нормативно-правові акти, основні наукові думки і правові позиції юристів щзодо діяльності різних держав у космічній галузі, діяльність Комітету з використання космічного простору в мирних иіляя та його Юридичного підкомітету.

Зроблено висновок, що на сьогодні базові акти міжнародного космічного права, відстають від розвитку науково-технічного прогресу, а відповідні структури ООН не в змозі вирішити всі нагальні проблеми космічної діяльності. Пропонується прийняти низку узгоджених нормативно-

(C) Svitlychnyy, Olexander, 2018 
правових актів міжнародного космічного права та створити нову організацію з питань космічної діяльності.

Ключові слова: право власності, космічні об'єкти, природні ресурси, міжнародне космічне право, нормативні акти, організація

Received: July 3, 2018; accepted: August 21, 2018

Advanced Space Law, Volume 2, 2018: 76-95.

https://doi.org/10.29202/asl/2018/2/10

\section{Постановка проблеми}

Українська земля дала світу видатних вчених, без яких складно уявити уявлення про космос та розвиток космонавтики. Микола Кибальчич, що народився на Чернігівщині, ще в XIX ст. розробив проект унікального літального апарату, який міг би здійснювати космічні польоти. Уродженець Полтави Юрій Кондратюк, ще у 1916 році розрахував оптимальну траєкторію польоту до нічного світила, які були використані американцями при підготовці польоту людини на Місяць. Під керівництвом уродженця Житомира Сергія Корольова був запущений перший штучний супутник Землі та відбувся перший політ людини у космос. Завдяки іншому українцю Валентину Глушко, було створено двигуни, на яких працювали практично всі радянські ракети-носії. Вагомий внесок у розвиток космонавтики було зроблено українськими підприємствами, серед яких особливе місце займали дніпропетровські Південний машинобудівний завод i конструкторське бюро «Південне», де у 1957 році було створено ракетоносій «Космос», який успішно використовувався для польотів в космос та інші космічні апарати, такі як «Метеор», «Стріла» і супутники з серії «Інтеркосмос».

I на сьогодні Українська держава є приймає активну участь в освоєнні Всесвіту, приймаючи участь у розробці космічних апаратів та здійснюючи їх запуск.

Внаслідок швидкому розвитку технологій, астрономи роблять нові відкриття у Всесвіті. Завдяки чому українські назви й імена увічнені в різноманітних космічних об'єктах. Зокрема, один з найбільших кратерів планети Меркурій носить ім'я Тараса Шевченка. На Венері один з кратерів назвали на

честь астронома і геофізика Зінаїди Аксентьевої, а на Марсі про Україну нагадують три кратера. Один названий на честь харківського планетолога Миколи Барабашова, а два інших — на честь міст Свпаторія і Фастів. Нарешті, на одному з супутників Юпітера увічнено ім'я стародавнього київського літописця Нестора. Ну, а на Місяці цілих дванадцять кратерів носять імена українських вчених, в тому числі Юрія Кондратюка, Сергія Корольова та Володимира Вернадського. Під номером 1709 в міжнародному каталозі значиться астероїд Україна. А мала планета № 2171 носить ім’я Київ — таку назву їй дали на честь 1500-річчя столиці України. $Є$ в космосі також астероїди Одеса, Полтава, Диканька, Херсон, Каховка, Суміана (в честь міста Суми), а «кримські» назви носять кілька десятків малих планет. Серед малих планет є Кобзар (в честь Тараса Шевченка), Каменяр (в честь Івана Франка), Леся (в честь Лесі Українки), а також Сковорода, Гоголь, Нарбут, Короленко, Параджанов, Довженко, Биков, Бабель і багато інших. А ще в міжзоряному просторі є астероїди Кнушевія (в честь Київського 
національного університету імені Шевченка) і Кіевтех (в честь Київського політехнічного інституту) [Галактика, 2018].

Проте, зареєстровані міжнародному каталозі космічні об'єкти, ім'я яких пов'язуємо із Україною, не є їі власністю, що в цілому відповідає міжнародному праву, зокрема, «Договору про принципи діяльності держав по дослідженню і використанню космічного простору, включаючи Місяць та інші небесні тіла» від 10.10.1967 р. (Договір про Космос) [Treaty, 1967].

Але на практиці виникла ситуація, коли внаслідок недостатньо чітко визначених положень міжнародного права, існуючих правових прогалин в «Договорі про Космос», певні особи, фактично, привласнюють собі космічні об'єкти, які є надбання всього співтовариства.

Метою даної статті є розкриття особливостей права власності на космічні об’єкти, аналіз нормативно-правових актів та наукових думок щодо використання космічних природних ресурсів надає можливість визначити та окреслити найближчі перспективи подальшого розвитку міжнародного космічного права та діяльності відповідних структур ООН.

\section{Виклад основного матеріалу}

За відсутності автентично визначених положень міжнародного космічного права, американець Денніс Хоуп вважає, що йому належить Місяць, але найцікавіше, що багато йому вірять і готові платити. Ніхто не заперечує його бізнес з продажу земельних ділянок на Місяці, Марсі, Венері, і Меркурії, а також різних об'єктів всесвіту. Його діяльність слабо підкріплена будь-якої правової основою, однак, ніхто не зупиняє його діяльність і Денніс Хоуп вважає свій бізнес цілком законним. Він звернув увагу на те, що існуючі міжнародні договори вказують лише на те, що планети і зірки не можуть належати державам і корпораціям, але в них ні слова не говориться про приватних осіб. Скориставшись цим упущенням в законодавстві, він оголосив себе власником усіх космічних об'єктів Сонячної системи, крім Землі і Сонця. Після цього він письмово повідомив про даний факт ООН, СРСР, США, Китай, Канаду і ін. країни, але відповіді, зі зрозумілих причин, не було. У листопаді 1980 р. він оформив «Декларацію про власність» на Місяць, Марс, Венеру, Меркурій, Іо (супутник Юпітера) відповідно до вимог міжнародного законодавства, законів США і нормативних документів ООН. Тоді ж, через засновану Хоупом компанію «Тhe Lunar Embassy», він почав свою діяльність 3 реалізації земельних ділянок планет Сонячної системи фізичним, юридичним особам 3 багатьох країн світу.

На сьогодні компанія The Lunar Embassy має офіційні представництва в 35-ти країнах світу: Канада, Великобританія, Ірландія, Франція, Японія, Австралія, Фінляндія та ін. Крім цього відкриті авторизовані офіси продажів інопланетної нерухомості в Німеччині, країнах Балтії, в Україні, Ізраїлі. У Росії з 1998 р. відкриті представництва Lunar Embassy в Москві і Санкт-Петербурзі.

Стандартний розмір 1 ділянки - 1 акр (40 соток). Площі придбаних ділянок i їх чіткі координати заздалегідь вносяться в Договори (Сертифікати) їх купівлі-продажу. Після продажу ділянки представник Місячного Посольства вписує ім'я його власника до Договору (Сертифікат) купівлі-продажу і повідомляє про факт продажу ділянки і ім'я його власника в офіс компанії Lunar Embassy, де ведеться єдиний реєстр власників. 
Після цього угоді і купленому на дане ім'я ділянці присвоюється реєстраційний номер. В даний час Денніс Хоуп продав близько 600 мільйонів акрів землі на Місяці. За його відомостями, землю в космосі вже купили 5 мільйонів чоловік з 193 країн землі. Серед власників земельних ділянок на інших планетах відомі політики, астронавти NASA, світові зірки кіно, музики і спорту [Lunar, 2019].

Проблема права на космічні об'єкти, піднята Деннісом Хоупом, знайшла своє нормативне закріплення. Одобрений 10.11 .2015 p. Сенатом США Закон «Про конкурентоспроможність комерційних запусків у космос» (The US Commercial Space Launch Competitiveness Act), 16.11.2015 p. Палатою предстаників та підписаний 25.11.2015 р. Президентом Обамою, став реальністю. Цей нормативний акт регулює різні аспекти, пов'язані з участю американського приватного сектора в космічній діяльності держави, але й дозволяє громадянам США вільно займатися розробкою планет і астероїдів, володіти і розпоряджатися отриманими ресурсами, в тому числі, водою і мінералами [US Commercial, 2015].

На думку президента Міжнародного інституту космічного права Тані Массон-Зван і ряду інших експертів, новий закон США про космічних ресурсах $є$ корисним для захисту комерційних інтересів, оскільки він заповнив існуючий правовий пропуск, явно і виразно встановлюючи і регулюючи ті права приватного сектора, які неявно (імпліцитно) має на увазі Договір про космос 1967 р. Наявність такого закону підвищує для інвесторів ступінь визначеності перспектив, що стосуються видобутку копалин за межами Землі, і одночасно основу для розробки в США та інших країнах допоміжних правових механізмів, що регулюють діяльність приватного сектора з видобутку ресурсів на Місяці та інших небесних тіл [Masson-Zwaan \& Richards, 2015].

Після цього, від 20.122015 р., Міжнародний інституту космічного права (International Institute of Space Law) висловив свою офіційну позицію, в якій зазначив, що через відсутність чіткої заборони на присвоєння космічних ресурсів в Договорі по космосу 1967 року, можна зробити висновок, що їх використання допускається. 3 цієї точки зору новий закон США $є$ можливим тлумаченням Договору по космосу. Тому, ще належить 3'ясувати, чи поділяють таке тлумачення інші держави, і в якій мірі [Position, 2015].

До прийняття США Закону «Про конкурентоспроможність комерційних запусків у космос», сприяли також й інші нормативні акти. Зокрема, «Угода про діяльність держав на Місяці та інших небесних тілах», прийнято резолюцією 34/68 Генеральної Асамблеї ООН від 05.12.1979 р., визнаючи, що Місяць, що є природним супутником Землі, грає важливу роль в дослідженні космосу, держави можуть отримати вигоди, які можуть бути отримані від розробки природних ресурсів Місяця та інших небесних тіл [Agreement, 1979].

Не тільки правові колізії правового регулювання міжнародного права щодо космічних об'єктів породило таку ситуацію, але й криза моралі призводить до того, що США іiі громадяни будуть задовольняти свої матеріальні інтереси за рахунок космічних об'єктів, що $є$ надбанням всього людства. До цього слід додати, що і в самих США до питання правового регулювання суспільних відносин викликає багато запитань. Невипадково суддя Олівер Вендел Холмс зазначає, що право - це стандарт який сторонам дозволено знати заздалегідь, а не питання залежності від примхи певного журі присяжних засідателів, але сьогодні на думку Філліппа Говорда, у правосуддя США немає такого стандарту. Під питання поставлено саме право громадян на судовий захист, дозвіл кому завгодно подавати позови, із-за будь-яких приводів, які не відповідають закону, а на 
проти, йому суперечать. На завершення цієї статті Філліпп Говорд процитував слова президента США Буша «Ми пройдемо довгий шлях до повернення здорового глузду в нашу систему юридичної відповідальності» [Howard, 2002].

Це не дивно, адже в самих США існуючі основні моделі права власності, оцінюється вкрай неоднозначно.

По праву США, майно підрозділяється на:

1. Реальне (realproperty, realty, realestate): земля і все, що з нею пов'язано, тобто фактично нерухоме майно;

2. Персональне (personalproperty, personalty, shattel): всі інші види майна, тобто фактично рухоме майно.

Право на нерухомість складається з права на землю і все, що знаходиться на поверхні землі, над землею, включаючи повітряний простір (з обмеженням для авіації), і під землею, включаючи підземні води і копалини, якщо інше не встановлено статутним або загальним правом [Тягай, 2011].

А ось варіативність системи складних структурних моделей права власності досягається за рахунок включення до їх складу речових прав вимагання (future interests). Суть правовимагання полягає в тому, щоб забезпечити можливість володаря такого права в перспективі стати безпосереднім власником, і безумовним власником нерухомого майна. Незважаючи на те, що така юридична категорія має властивості нехарактерними для континентальних уявлень про право власності, вона тим не менш, $є$ повноцінною речове-правовою конструкцією, наділяє суб'єктів не майбутнім, а реальним правом. Це підтверджується тим, що речове правовимагання може передаватися за договором, а також успадковуватися за заповітом і за законом [Тягай, 2011].

У Китайській народній республіці регулювання речових прав здійснюється відповідно до Закону КНР «Про речові права» від 16.03.2007 р., що діє з 01.10. 2007 р. Згідно ст. 2 Закону до речей закон відносить нерухоме та рухоме майно. Придбання i здійснення речових прав повинні відповідати законодавству, нормам суспільної моралі, не завдавати шкоди громадським інтересам і законним інтересам інших осіб (ст. 7). Згідно ст. 24 Закону КНР режим рухомого майно може бути поширений водні судна, повітряні судна та автотранспортні засоби [Закон, 2007].

Стаття 130 Цивільного кодексу Російської Федерації, яка має назву «Нерухомі і рухомі речі», до нерухомих речей відносить (нерухоме майно, нерухомість) відносяться земельні ділянки, ділянки надр і все, що міцно пов'язане із землею, тобто об'єкти, переміщення яких без невідповідного збитку їх призначенню неможливе, в тому числі будівлі, споруди, об’єкти незавершеного будівництва. До нерухомих речей належать також повітряні і морські судна, судна внутрішнього плавання. Законом до нерухомого майна може бути віднесено і інше майно. До нерухомого майна відносяться житлові та нежитлові приміщення, а також призначені для розміщення транспортних засобів частини будівель або споруд (машино-місця), якщо кордону таких приміщень, частин будівель або споруд описані в установленому законодавством про державний кадастровому обліку порядку.

Речі, не віднесені до нерухомості, включаючи гроші і цінні бумаги, визнаються рухомим майном. Реєстрація прав на рухоме майно не вимагається, крім випадків вказаних в законі [Гражданский кодекс, 1994]. Тобто, Цивільний кодекс Російської Федерації поширив режим нерухомості на космічні об'єкти, але не прирівняв їх до нерухомості. 
У зв’язку з неоднозначним трактуванням норм вказаної статті щодо поділу речей на рухоме і нерухоме, Федеральна податкова служба Російської Федерації рекомендувала застосовувати сформовану судову практику. Наприклад, річ є нерухомої, якщо:

a) вона $є$ такою в силу свої природних властивостей;

b) в силу прямої вказівки федерального закону, відповідно до якого об'єкт підпорядкований режиму нерухомих речей (абз. 1-2 п. 1 ст. 130 ЦК РФ, визначення Верховного Суду Російської Федерації від 07.04. 2016 р. у справі № 310-ЕС1516638 [Определение, 2016].

Ми невипадково проаналізували норми законів США, Російської Федерації та КНР, адже саме ці держави є найбільш потужними гравцями космосу.

Згідно ст. 181 Цивільного кодексу України до нерухомих речей (нерухоме майно, нерухомість) належать земельні ділянки, а також об’єкти, розташовані на земельній ділянці, переміщення яких є неможливим без їх знецінення та зміни їх призначення. Режим нерухомої речі може бути поширений законом на повітряні та морські судна, судна внутрішнього плавання, космічні об’єкти, а також інші речі, права на які підлягають державній реєстрації. Рухомими речами є речі, які можна вільно переміщувати у просторі [Цивільний кодекс, 2003].

Взагалі, поділ речей на рухомі і нерухомі відомо ще в Римському цивільному праві класичного періоду (III століття до н. Е. - III століття н. Е.). До рухомих відносилися просторово переміщувані речі, а до нерухомих - земельні ділянки і все створюване на них, а крім того - надра, простір над землею. Вважалося, що зроблене над поверхнею слідує за поверхнею [Косарев, 2007: 82].

На відміну від законодавства США, Російської Федерації і Китайської Народної Республіки, чинне законодавство України визначає космічний об'єкт як рухоме майно. Для визначення правового режиму космічного об'єкта доцільно дослідити його правовий статус. Абзац 2 частини першої ст. 181 Цивільного кодексу України до нерухомості відносить і деякі рухомі за своїми природними властивостями речі: режим нерухомої речі може бути поширений законом на повітряні та морські судна, судна внутрішнього плавання, космічні об’єкти, а також інші речі, права на які підлягають державній реєстрації [Цивільний кодекс, 2003].

Це означає, що поширення режиму нерухомості на космічні об'єкти можливе тільки на підставі прямого припису закону. Тобто усі питання, пов'язані з космічним об'єктом, знаходяться в компетенції держави.

В міжнародних правових актах, а також національних законах існують різні терміни: космічні кораблі, космічні системи, космічні апарати, тощо, але в якості загального родового поняття більше всього вживають термін «космічні об'єкти». Також мається на увазі технічні прилади (апарати), створені людиною для використання в космічному просторі, а також для польоту на інші планети.

Отже, з метою з'ясування правового режиму космічних об'єктів, підлягає визначення поняття «космічні об’єкти», які містяться в нормативно-правових актах.

На думку авторського колективу навчального посібника «Державні облікові системи по управлінню і розвитку територій Російської Федерації (кадастри, реєстри, регістри)», у діючих міжнародних угодах по космосу немає визначення космічного об'єкта. Спроби розробити таке визначення робилися як в дипломатичній практиці, так і в доктрині. В ході роботи над Конвенцією 1972 про міжнародну відповідальність за шкоду, заподіяну космічними об'єктами, з пропозиціями щодо такого визначення виступали Бельгія, 
Угорщина, Індія, спільно Австралія та Канада, Польща, Аргентина. Однак загальною згодою (консенсусу) з цього питання досягти не вдалося, і було вирішено не давати такого визначення. 3 урахуванням попереднього досвіду в подальшому подібного роду спроби не робилися. Винятком із загального правила є два нині недіючих документа, в яких містилося визначення космічного об’єкта. Перш за все це Конвенція 1962 року про створення Європейської організації з розробки ракет-носіїв (ЕЛДО), в якій космічний об’єкт визначений як «апарат, призначений для виведення на орбіту в якості супутника Землі або іншого небесного тіла, або для польоту по іншій траєкторії в космічному просторі». У 1971 році на Всесвітній адміністративної конференції радіозв'язку космічний об'єкт був ототожнений з космічним кораблем і визначено як «створене людиною засіб пересування, призначене для запуску за межі основної частини земної атмосфери» [Государственные, 2016: 84]. Чи це так, звернемося до нормативних актів.

Варто підкреслити, що вперше питання пов'язане із космічним простором i небесними тілами, було озвучено на 1085 пленарному засіданні Генеральної асамблеї ООН від 20.121961 р. Було вказано, що космічний простір і небесні тіла доступні для дослідження і використання всіма державами, космічний простір і небесні тіла не підлягають державній власності будь-якою державою світу [Резолюції, 1961].

Однак міжнародно-правову оцінку космічна діяльність вперше отримала в «Декларації правових принципів, що регулюють діяльність держав 3 дослідження і використання космічного простору», підготовленої Комітетом ООН по космосу i одноголосно прийнятій Генеральною Асамблеєю ООН 13.12. 1963 р. В Резолюції 1962 (XVIII) наголошується, що дослідження і використання космічного простору здійснюються на благо і в інтересах усього людства. Космічний простір і небесні тіла відкриті для дослідження і використання всіма державами на основі рівності і відповідно до міжнародного права. Космічний простір і небесні тіла не підлягають національному присвоєнню ні шляхом проголошення суверенних прав, ні за допомогою або окупації, ні будь-якими іншими засобами. Діяльність держав 3 дослідження і використання космічного простору повинна здійснюватися відповідно до міжнародного права, включаючи Статут Організації Об’єднаних Націй, в інтересах підтримки міжнародного миру і безпеки і розвитку міжнародного співробітництва і взаєморозуміння. Держави несуть міжнародну відповідальність за національну діяльність у космічному просторі незалежно від того, чи здійснюється вона урядовими або неурядовими органами, і за забезпечення відповідності національної діяльності принципам, викладеним у цій Декларації. Діяльність неурядових органів в космічному просторі проводиться з дозволу та під постійним наглядом відповідної держави. У разі діяльності в космічному просторі будь-якої міжнародної організації відповідальність за виконання принципів, викладених у цій Декларації, покладається на дану міжнародну організацію і на беруть в ній участь. При дослідженні і використанні космічного простору держави керуються принципом співробітництва і взаємної допомоги і здійснюють всю свою діяльність в космічному просторі з належним урахуванням відповідних інтересів інших держав. Якщо яка-небудь держава має підстави вважати, що діяльність в космосі або експеримент, заплановані цією державою або його громадянами, утворять потенційно шкідливі перешкоди діяльності інших держав в справі мирного дослідження і використання космічного простору, то воно повинно провести відповідні міжнародні консультації, перш ніж приступити до такої діяльності або до такого експерименту. Держава, має підстави вважати, що діяльність в космосі або експеримент, запланований іншою державою, 
утворять потенційно шкідливі перешкоди діяльності у справі мирного дослідження і використання космічного простору, може вимагати проведення консультацій щодо такої діяльності або такого експерименту [Декларация, 1963].

У розумінні Декларації, під космічним об'єктом слід розуміти «об'єкт», який занесено до реєстру держави та запущено у космічний простір (п. 7), так і «предмет», запуск якого здійснено у космічний простір (п. 8) [Декларация, 1963].

Слід наголосити, що основні принципи Декларації 1963 (XVIII) було покладено «Договір про принципи діяльності держав по дослідженню і використанню космічного простору, включаючи Місяць та інші небесні тіла» (Договір про космос) від 10.10.1967 p., який встановив основні принципи космічної діяльності держав. Стаття 2 Договору визначає космічний простір, включаючи Місяць та інші небесні тіла як космічні об’єкти, які не підлягають національному присвоєнню ані шляхом проголошення на них суверенітету, ані шляхом використання або окупації, ані будь-якими іншими засобами [Treaty, 1967]. Цей Договір було підписано трьома державами: США, СРСР і Великобританією. Зараз до нього приєдналися більше ста держав. При цьому в СРСР законодавство про регулювання космічної діяльності практично було відсутнє і фактично здійснювалося адміністративними методами. На відміну від США де національна політика часто зустрічається в урядових директивах, виконавчих розпорядженнях або указах. Технологічні досягнення, програми змінюються, і обставини змінюються в тій мірі, в якій необхідні додаткові закони для забезпечення відповідного охоплення. Першим великим законом у Сполучених Штатах був Закон «Про національну аеронавтику i космос» 1958 року, яким було утворено Національне управління по аеронавтики i дослідження космічного простору (NASA), яке діє і до цього часу. Цей закон визначив основні національні політики щодо діяльності у просторі [Sundahl \& Gopalakrishnan, 2011: 20].

Водночас в останні роки тенденції правового регулирования США у сфері космічної діяльності дещо змінилися. Військова діяльність суттєво доповнюється комерційною. Це стосується не тільки США, але й інших держав. 16.11.2016 р. Парламентом Японії було прийнято Закон «Про космічну діяльність», який визначає порядок державного нагляду і допуску до космічних пусків підприємств, які займаються пусками ракет і супутників. На думку професора відділення юридичних досліджень аспірантури Університету Кейо Аокі Сецуко, основна мета японського Закону «Про космічну діяльність» — це розширення бізнесу, пов'язаного з космосом. Успішність бізнесу, поряд з технологічним розвитком і залученням фінансування, визначається і створенням належного режиму i правил. Нинішній Закон, безумовно, буде сильно сприяти розвитку космічного бізнесу Японії, яка має в повній мірі володіє необхідним технологічним рівнем і потенціалом. Ймовірно, вже протягом найближчих років венчурні підприємства приступлять до виконання запусків малих ракет-носіїв з компактними супутниками [Setsuko, 2017].

Визначаючи важливість вивчення і освоєння космічних об'єктів, не осторонь від цих питань стоять й інші держави, зокрема, європейські. 30.05.1975 р., Німеччина, Бельгія, Данія, Іспанія, Франція, Ірландія, Італія, Норвегія, Нідерланди, Великобританія, Швеція, підписали «Конвенцію про створення Європейського космічного агентства», метою якої було інтегрувати європейські національні космічні програми в європейську національну космічну програму, що вступила в силу 30.10 .1980 р. У розумінні Конвенції під космічними об'єктами слід розуміти: космічні системи (ст. 5); ракети-носії та інші космічні транспортні системи (ст. 8); об’єкти (ст. 9) [Конвенція, 1975]. 
Вважаючи, що обов’язкова система реєстрації об'єктів, що запускаються в космічний простір, сприятиме, зокрема, їх ідентифікації і застосуванню і розвитку міжнародного права, що регулює дослідження і використання космічного простору, 15.09. 1976 р. ООН було прийнято «Конвенцію про реєстрацію об'єктів, що запускаються в космічний простір». Пункт b) ст. 1 Конвенції, визначає, що термін «космічний об'єкт» включає складові частини космічного об'єкта, а також засіб його доставки і його частини [Конвенція, 1975a]. Як бачимо цей нормативний акт, також не надає визначення, що слід розуміти під «космічним об'єктом», а лише визначає його складові, а також засіб його доставки і його частини.

Стаття 8 «Угоди про діяльність держав на Місяці та інших небесних тілах», теж вживає термін «космічний об'єкт» та визначає термін «космічні апарати», який включає складові його частини, обладнання, установки, станції і споруди, також не надає визначення, що слід розуміти під «космічним апаратом» [Agreement, 1979].

При цьому як зазначають Сергій Васьков та Сергій Малков, в юридичному сенсі космічний апарат — це космічний об'єкт, або його складова частина призначена для функціонування в космічному просторі, включаючи небесні тіла. Міжнародний правовий режим космічного апарата — дотичний правовому режиму космічного об'єкта. Відмінна особливість більшості космічних апаратів - здатність до самостійного функціонування в умовах космосу (глибокий вакуум, невагомість, інтенсивна радіація, наявність метеоритних часток і т. п.), з урахуванням яких створюється його конструкція. Космічний апарат оснащується науковими приборами, системами терморегуляції, енергозбереженням, управлінням руху, радіозв'язком із Землею та іншими космічними апаратами, а у випадку находження на них людей або тварин - системами життєзабезпечення, відповідними приборами і т. п. [Васьков \& Малков, 2003: 15].

Незважаючи на назву «Космічні об’єкти» (ст. 17) Закону Російської Федерації «Про космічну діяльність» від 20.08.1993 р., закон не дає відповіді, що слід розуміти під космічним об'єктом, а лише визначає: порядок реєстрації; їх приналежність; контроль над зареєстрованими в РФ космічними об'єктами; права власності на космічні об'єкти [Закон РФ, 1993]. На відміну від Закону України «Про космічну діяльність» від 15.11. 1996 р., в якому зазначено, що об' єктами космічної діяльності (космічна техніка) є матеріальні предмети штучного походження, що проектуються, виготовляються та експлуатуються як у космічному просторі (космічний сегмент, космічна інфраструктура), так і на поверхні Землі (наземний сегмент, наземна інфраструктура) з метою дослідження та використання космічного простору [Про космічну, 1997].

Із наведених нормативно-правових актів випливає, що космічні об'єкти та їх складові — це штучні об’єкти, що створюються для космічної діяльності.

Як на нашу думку, такий підхід до визначення терміну «космічні об’ єкти» є дещо звуженим і його слід розглядати у вузькому розумінні, оскільки не враховує й інші космічні об'єкти Всесвіту. У широкому розумінні до космічних об'єктів слід віднести всі об'єкти галактики та всі природні космічні об’єкти Сонячної системи, а також небесні тіла.

Існуючі правові колізії у міжнародному праві все більше призводить до комерціалізації космічної діяльності, але й мілітаризації космосу, ставить на порядок денний вести мову про існуюче космічне право. Так, на конференції, яка відбулася в Мадриді у жовтні 2016 року і була присвячена темі «Напередодні п’ятдесятиріччя Договору по космосу», де 3 основною доповіддю виступила професор Іберо-американського інституту повітряного і космічного права та комерційної авіації Морін Вільямс, на думку якої положення 
Договору по космосу характеризуються гнучкістю, до цього дня залишається актуальним і відповідає різній практиці космічної діяльності. Якщо будуть потрібні будь-які коригування, їх слід вносити в окремому міжнародно-правовому документі, при цьому зберігаючи базові елементи і принципи Договору по космосу, У зв’язку 3 цим ключове значення для розвитку космічної діяльності та космічного права мають міжнародне співробітництво, інтеграція і партнерство [Інформація, 2017].

Не осторонь від цих питань стоїть і відповідні структури ООН. Тому, важливу роль в регулюванні проблемних питань космічної діяльності повинна відігравати Асоціація міжнародного права (АМП) відома своєю відкритою політикою і великими зовнішніми зв'язками. Головним завданням якої є вивчення, роз'яснення та розвиток міжнародного публічного і приватного права і підготовка досліджень 3 порівняльного правознавства, а також та Комітет з космічного права, створений 1958 року в Нью-Йорку в рамках АМП. Так, Комітет АМП констатує, що на сьогодні жодного юридичного визначення суборбітального польоту до сих пір не прийнято. Визначення, запропоноване ІКАО (політ на вельми великій висоті, що не передбачає виведення літального апарату на орбіту), до цього часу не знайшло відображення ні в одному національному або міжнародному документі, що має обов'язкову юридичну силу. У юридичній літературі замість цього терміну нерідко використовується термін «неорбітальні польоти». Іншим актуальним питанням на порядку денному є досі неврегульований юридичний статус космічних природних ресурсів і діяльності по їх видобутку на Місяці та інших небесних тілах [Аннотированная, 2017].

Існуючі недостатньо чітко визначені положення міжнародного права та «Договору про Космос», завдяки яким будь-яка особа може привласнити космічні об'єкти, здійснювати видобуток корисних копалин тощо, породжує різноманітні дії урядових і неурядових організацій різних держав у цьому напрямку.

Після того як США в 2015 році був прийнятий закон US «Commercial Space Launch Competitiveness Act», який заклав правові основи для приватного вивчення космосу i експлуатації його природних багатств, британський професор права Г. Одунтан висловив думку, що Договір про космос 1967 року в принципі забороняє видобуток корисних копалин на астероїдах в будь-яких цілях, окрім цілей наукових досліджень, приватне привласнення і продаж космічних ресурсів 3 метою отримання прибутку суперечать ідеї використання космосу на користь і в інтересах всіх країн. Він вважає, що відносно космічних ресурсів всі держави повинні слідувати старому правовому принципу римлян: «Те, що стосується всіх, має бути всіма обговорено і схвалено» (Quod omnes tangit, ab omnibus tractari et approbari debet). Такої думки дотримуються й інші науковці [Lefeber, 2016].

Після прийняття США Закону «Commercial Space Launch Competitiveness Act», який заклав правові основи для приватного вивчення космосу і експлуатації його природних багатств, Люксембург став першою європейською країною і другою у світі після США, яка прийняла у 2016 році закон, що дозволяє приватним компаніям вести видобуток корисних копалин в космосі, повідомляє «Metalinfo». Цей нормативний акт встановлює процедури затвердження космічних видобувних проектів, порядок комерційного використання ресурсів і принципи контролю над реалізацією проектів [Люксембург, 2017].

Як свідчить Закон Люксембургу, що вступив в силу з 01.08. 2017 р., підприємства, які мають офіс в Герцогстві, можуть отримати в уряду країни дозвіл на використання космічних ресурсів. На відміну від закону, прийнятого в США, документ вимагає не 
підконтрольності підприємств Люксембургу, а лише наявності представництва на території країни. Уже п’ять іноземних космічних компаній, в тому числі з США і Японії, уклали офіційні угоди про початок роботи на території країни. За повідомленнями уряду, ще близько 60 підприємств повідомили про свій намір відкрити представництва. Для залучення на свою територію компаній Люксембург також планує інвестувати 200 мільйонів євро в пов'язані з космосом проекти [Люксембург, 2017].

За оцінками «Planetary resources» — компанії, які вже влаштувалися в Люксембурзі, — вартість видобутих у корисних копалин може становити трильйони доларів. Вартість середнього багатого платиною астероїда на світовому ринку становить близько 3 трильйонів доларів, а астероїда із замороженою водою - близько 5 трильйонів доларів. «Навколо Землі обертається понад 14000 космічних тіл, доступних для видобутку корисних копалин, - заявив віце-прем’єр Люксембургу Етьєн Шнайдер. - Близько 10 відсотків цих тіл мають значну цінність і містять матеріали, які будуть потрібні нам в майбутньому. Але найважливіше зараз для нас — лід, який знаходиться на Місяці і на астероїдах. 3 нього можна добувати водень і заправляти цим паливом супутники» [Planetary, 2019].

Слід підкреслити, що обговорення правових аспектів космічних природних ресурсів і видобутку корисних копалин з астероїдів, було здійснено на робочому засіданні в Йоганнесбурзі Комітетом АМП по космічному праву, що стосуються правового статусу космічних природних ресурсів, які не були врегульовані «Договором про принципи діяльності держав з дослідження і використання космічного простору, включаючи Місяць $\mathrm{i}$ інші небесні тіла», i «Угодою про діяльність держав на Місяці та інших небесних тілах». Питання про видобуток корисних копалин в космосі був включений до порядку денного засідання в світлі прийняття у 2015 році США Закону «Про конкуренцію серед приватних комерційних перевізників (H.R. 2262) і публікація заяви Ради директорів МІКП 3 цієї нагоди 20.12. 2015 р. Обидва документи можна розглядати як одне з можливих трактувань права, що заохочує свободу видобутку копалин в космосі. Що не виключає можливості інших трактувань з боку інших держав і / або міжурядових і міжнародних неурядових організацій, що не виключає можливості прийняття документа, який може не мати обов'язкової юридичної сили міжнародного документа, ідея розробки якого набуває все більшої популярністю. В наслідок чого деякі із членів Комітету АМП з космічного права висловили занепокоєння у зв'язку з розколом в міжнародному співтоваристві 3 питання про масштаби видобутку копалин в космосі [Аннотированная, 2017].

Ці та інші дискусії було продовжено на засідання юридичного підкомітету Комітету по використанню космічного простору Генеральної Асамблеї ООН у 2017 році (А/ AC.105/1122), де багатьма делегаціями держав було висловлено думку, що спроби деяких держав здійснювати космічну діяльність в обхід зобов'язань, передбачених Договором про космос, $є$ приводом для занепокоєння. Тому, прикладами такої практики держав можуть служити: а) визнання законним здійснення національними недержавними організаціями таких видів діяльності з освоєння космічних ресурсів, які суперечать положенням Договору; i b) реєстрація приватних комерційних структур, зацікавлених у освоюванні космічних ресурсів, або надання їм права здійснювати таку діяльність під своїм прапором. У зв'язку з цим було відзначено, що Підкомітету слід пояснити значення таких ключових понять, як «спільну спадщину людства», «спільне надбання людства», «національне привласнення космічного простору» і «розробка/дослідження космічних ресурсів» [Аннотированная, 2017]. 
Отже, діяльність Комітету Організації Об’єднаних Націй сприяє забезпеченню використання космічного простору в мирних цілях і надає можливості для всіх держав скористатися благами космічної діяльності. Комітет і його підкомітети щорічно проводять засідання, на яких розглядаються питання, передані їм Генеральною Асамблеєю, доповіді, які подаються нею, і питання, підняті державами-членами. Працюючи на принципах консенсусу, Комітет розробляє рекомендації для Генеральної Асамблеї. Робота Комітету і його юридичної підкомітету дозволила Генеральній Асамблеї прийняти п'ять юридичних документів, які продовжують залишатися в силі, й на які ми уже звертали свою увагу На підставі роботи Комітету та його юридичного підкомітету Генеральна Асамблея затвердила принципи здійснення космічної діяльності, в тому числі: принцип використання державами штучних супутників Землі для міжнародного безпосереднього телевізійного мовлення, таке використання має міжнародні політичні, економічні, соціальні і культурні наслідки; принцип, що стосуються дистанційного зондування Землі з космічного простору, підтверджують, що ця діяльність повинна проводитися в інтересах всіх країн 3 повагою до суверенітету всіх держав і народів над їх природними ресурсами, а також прав та інтересів інших держав; принципи, що стосуються використання ядерних джерел енергії в космічному просторі. Комітетом також було розроблено Декларацію про міжнародне співробітництво в дослідженні та використанні космічного простору на благо та в інтересах усіх держав, з особливим урахуванням потреб країн, що розвиваються (1996 рік), констатує, що держави вільні у визначенні всіх аспектів своєї участі в міжнародному співробітництві в космічній галузі на рівноправній і взаємоприйнятної основі і що зацікавлені держави повинні здійснювати таке співробітництво найбільш ефективними і належними способами [Аннотированная, 2017].

При ухваленні рішень Комітет дотримується принципу консенсусу. Як вказують зарубіжні вчені, «очевидно, що консенсус це вкрай бажаний спосіб досягнення міжнародної згоди по трьом причинам [Space Law, 1992: 248-249]:

1. Процес пошуку угоди спокійний, він раптово не переривається голосом, який може зруйнувати все те, що могло б бути досягнуто, якщо б було відведено більше часу, як це відбувається в процесі переговорів при консенсусі;

2. Ситуація може бути така, що більшість голосів не гарантує практичної реалізації того чи іншого рішення, особливо якщо імплементація прийнятого рішення, в тому числі з питань фінансування, забезпечення персоналом, технологічної експертизи, залежить від тих держав, які голосували проти прийнятих заходів;

3. Колективна солідарність в процесі прийняття рішення забезпечує максимальну узгодженість при втіленні в життя і підтримці прийнятих рішень для загальної вигоди.

Незважаючи на часті обговорення та прийняті 3 проблемних питань космічної діяльності Резолюції ООН, вони все ж не встигають за активною політикою окремих держав та прийняттям ними нормативних актів 3 питань космічної діяльності. Після прийняття Закону США «Commercial Space Launch Competitiveness Act», окремі дослідники звертають увагу, що цей Закон став свого роду провокацією для міжнародної спільноти, але провокацією корисною. Причому, реальна користь цього закону полягає не в конкретних рішеннях, які він пропонує, а в тому, що цей акт акцентує увагу на необхідності якнайшвидшої ревізії та модернізації міжнародних угод по дослідженню і використанню космічного простору [Rummel, 2015]. 
За відсутності реакції міжнародних організацій на прийняті США та Люксембургом нормативних актів щодо використання природних космічних ресурсів, Президентом США Дональдом Трампом була репрезентована Національна космічна стратегію Америки «National Space Strategy». Відповідно до якої Національна космічна стратегія адміністрації Трампа ставить на перше місце інтереси Америки, забезпечуючи стратегію, яка зробить Америку сильної, конкурентоспроможної і великої. Нова стратегія підкреслює динамічний і спільне взаємодія між сектором національної безпеки, комерцією і цивільних космічних сектором та гарантує, що міжнародні угоди ставлять інтереси американських людей, працівників і підприємств на перше місце. Національна космічна стратегія прямо встановлює, що забезпечення космічної науки, комерційної вигоди і національної безпеки є головним пріоритетом для цієї адміністрації. Космічна стратегія грунтується на Стратегії національної безпеки, через силу в космічній сфері, і захищає життєво важливі інтереси в космосі - для забезпечення безперешкодного доступу до космосу і свободи його роботи з метою забезпечення безпеки, економічного процвітання і наукових знань Америки. В рамках Національної космічної стратегії 30.06. 2017 р. Президент відродив Національну космічну раду вперше за 24 роки, а 11.12. 2017 р. президент США ще раз звернув увагу Америки на космічні об'єкти, підписавши Директиву з космічної політики, в якій Національному управлінню 3 аеронавтики і дослідженню космічного простору було доручено повернути американських астронавтів на Місяць для довгострокового дослідження і використання, людської місії на Марс та інші напрямки [President, 2018].

Крім США й інші держави долучилися о програм по освоєнню космічних об'єктів. Так, Китай презентув модель марсіанської бази, яка будується в провінції Цинхай. За повідомлення видання «China Daily», база стане першим у своєму роді науково-практичним комплексом в Китаї, який об'єднає сфери космосу, астрономії, геології, метеорології і нової енергетики, - пояснив глава відділу досліджень Місяця і глибокого космосу Китайської академії наук Лю Сяоцюнь. У 2020 році Китай збирається запустити на Марс космічний корабель для масштабних досліджень планети. Уряд Китаю вже схвалив програму по вивченню Марса, і через два роки з космодрому «Веньчан» в провінції Хайнань буде запущена ракета-носій «Чанчжен-5» ( «Великий похід-5»), яка повинна безпосередньо вивести на перехідну орбіту Землі і Марса зонд для дослідження Марса. Більш того, Китай вже оголосив міжнародний конкурс з відбору назви і емблеми для своєї першої дослідницької місії на Марс. Як розповіли в Китайській академії космічних технологій (CAST), переліт від Землі до Марса займе сім місяців.

У свою чергу Віце-президент США Майк Пенс, виступаючи в центрі Національного управління з аеронавтики і дослідженню космічного простору (NASA) в X'юстоні, заявив, що висадка людини на Місяць і Марс, а також дослідження глибин космосу $\epsilon$ частиною урядової політики Вашингтона, підкріпленої належним бюджетом. Вона закріплена в Директиві з політики в галузі дослідження космосу (Space Policy Directive 1), підписаної Дональдом Трампом. У 2017 році в США на дослідницькій станції «Мars Desert Research Station», яка знаходиться посеред пустелі американського штату Юта (iі рельєф також часто порівнюють з рельєфом Червоної планети), почалося моделювання «марсіанської експедиції». Відібрані на конкурсі добровольці будуть жити в умовах, подібних до умов на Марсі. У замкнутому просторі вони будуть відпрацьовувати навички, необхідні для колонізації Червоної планети. 
У «Роскосмосі» теж заявили, що почнуть готуватися до польоту на Марс в 2019 році та збираються витратити близько 100 мільйонів доларів на реалізацію проекту «ЕкзоМарс». Це спільне з Свропейським космічним агентством (ЄКА) підприємство, метою якого є дослідження Марса і пошук доказів існування в минулому і сьогоденні життя на Червоній планет.

В Об’єднаних Арабських Еміратах також заявили про плани створення населеного марсіанського міста до 2117 році. I шанси, а точніше фінанси на це у OAE є. У 2015 році OAE заснували власне космічне агентство. Країна планує інвестувати істотні суми в космічні програми, розраховуючи отримати вигоду не тільки в космосі, але і на Землі. В рамках проекту, що отримав назву «Марс-2117», передбачається в умовах міжнародного співробітництва створити на цій планеті жило міні-місто. В рамках проекту на базі національних університетів ОАЕ будуть створені науково-дослідні центри, а також буде істотно посилено науково-технічна база країни.

Індія також має свої види на Червону планету. Вона вже запустила дослідницький зонд «мангальян», який після дев'ятимісячного подорожі восени 2014 року вийшов на марсіанську орбіту. «Магнальян-2» планують запустити в 2020 році, і він буде складатися вже з орбітальної станції і модуля, що спускається. До речі, Індія - перша країна, якій вдалося досягти Марса $з$ першої спроби. Робота над «Мангальяном-2» ведеться спільно з французьким космічним агентством [Тимофеев, 2018].

Важливо відзначити, що за відсутності чітких міжнародних правил щодо космічних об'єктів, все більше держав, під впливом приватного бізнесу взяли політичний курс на комерціалізацію космосу. На думку Антона Первушина, дійсного члена Федерації космонавтики Росії, сучасна космонавтика багато в чому підпорядкована інтересам комерції. Оскільки з'ясувалося, що найближчі планети непридатні для життя, а доставка вантажів на орбіту ще довго буде залишатися дорогим і складним справою, пріоритет віддається створенню та підтриманню супутникового угруповання, яка вирішує безліч комерційних завдань: картографування, навігація, трансляція даних, спостереження за погодою і пошук ресурсів. На другому місці стоїть наука, причому не тільки фундаментальна, але і має практичне значення. Скажімо, існування такого дорогого комплексу, як Міжнародна космічна станція (МКС), можна виправдати тільки інтересами науки перш за все науки про людину, його взаємодії з новим середовищем проживання і т.п. I тільки на третьому місці, на жаль, знаходиться завдання розширення нашої присутності у позаземне просторі, колонізації Місяця і Марса, безпосереднього вивчення малих тіл Сонячної системи, включаючи астероїди [Шикарев, 2018].

Ми вважаємо, що сучасна космонавтика в першу чергу підпорядкована інтересам великих комерційних структур. Іншими словами, як зазначає Ілля Хель, космос відкритий для бізнесу. Саме так людство колонізує околиці Місяця, Місяць, астероїди, Марс і інші об'єкти - за допомогою рогу достатку розподіленої, комерційної екосистеми, яка в нескінченну кількість разів могутніше будь-якої окремої компанії або держави [Хель, 2018].

В підтвердження активної діяльності комерційних структур в космічній діяльності, наведемо найбільш відомі із них. Найбільш відомою є приватна компанія Ілона Маска «SpaceX» (США), яка займається будівництвом космічних об'єктів та космічними запусками, інші приватні компанії США: «Amazon», «Virqin Galactic», «Orbital ATK», «Lab Rocket», а також приватні компанії інших держав: «Interstellar Ttchnoloqies» (Японія), «OneSpace» (Китай), займаються різноманітною комерційною космічною діяльністю. 
Використовуючи у різних цілях космос та космічні об’єкти, діяльність суб'єктів такої діяльності повинна відповідати нормам міжнародного права. Як слушно зазначав, ще в 20-х роках минулого століття засновник української школи міжнародного права Володимир Корецький «...існують світогосподарські відносини, значить, повинні існувати (і дійсно існують) норми, що регулюють ці відносини, А якщо існують норми, які регулюють цю групу відносин, то ( при винятковому розвитку узагальнюючих тенденцій в праві) повинна була народитися система цих норм» [Корецький, 1989: 120121]. Погоджуючись із наведеною думкою, слід наголосити, що незважаючи на активну участь у різноманітній космічній діяльності приватного капіталу, провідну роль у цій діяльності повинні відігравати держави.

Серед значної кількості міжнародних угод, конвенцій та інших актів, які можуть вплинути на розвиток в майбутньому видобутку корисних копалин в космосі, найбільш застосовними з них є наступні: «Договір про принципи діяльності держав по дослідженню і використанню космічного простору, включаючи Місяць та інші небесні тіла» від 10.10.1967 р.; «Конвенція про міжнародну відповідальність за шкоду, заподіяну космічними об’ єктами» від 01.09.1972р.; «Конвенції про реєстрацію об’єктів, що запускаються в космічний простір» від 15.09.1976 р.; «Конвенція про оперативне оповіщення про ядерну аварію» від 27.10. 1986 р. [48]; «Конвенція про допомогу в разі ядерної аварії або радіаційної аварійної ситуації» від 26.02.1987 р.; «Принципи використання джерел ядерної енергії у відкритому космосі» від 14.12. 1992 р.

В контексті нашого дослідження важливого значення набуває «Угода про діяльність держав на Місяці та інших небесних тілах» від 18.12. 1979 р., в ст. 4 якої міститься припис «Дослідження і використання Місяця є надбанням всього людства і здійснюється на благо і в інтересах всіх країн, незалежно від ступеня їх економічного або наукового розвитку.

Отже, діючи на сьогодні нормативно-правові акти та норми міжнародного права не в змозі вирішити існуючі проблеми космосу, у тому числі заборону на комерційне використання і продажу космічних природних ресурсів. На недоліки міжнародного права у регулюванні космічної діяльності неодноразово звертають свою увага як структурні підрозділи Генеральної Асамблеї ООН, так і науковці. Як приклад, у доповіді Комітету з використання космічного простору в мирних цілях п’ятдесят сьомої сесії (черень 2014 року) Генеральної Асамблеї ООН, було висловлено думку, що на міжнародному співтовариству найближчим часом необхідно створити юридично зобов'язуючий документ з розробки космічних ресурсів в комерційних цілях на основі міжнародного консенсусу з метою забезпечення застосування міжнародного права до такої діяльності, оскільки в цій інноваційної галузі космічної діяльності потрібна юридична визначеність, а тому слід розробити універсальну всеосяжну конвенцію по космосу, щоб знайти рішення існуючих проблем, що дозволить вивести міжнародно-правовий режим космічного простору на наступний рівень його розвитку, оскільки принципи, зафіксовані в існуючих документах з космічного права, створили основу, що сприяє використанню та дослідження космічного простору для держав як здійснюють, так і не здійснюють космічні програми.

Отже, постає питання про необхідність створення дієвого міжнародного правового акту, який би врегулював існуючі проблеми космічної галузі, утому числі й загальне розуміння принципів використання космічних ресурсів — це не перспектива, а потреба сьогодення. 
Розвиток науки і техніки, свідчить про те, що на сьогодні діючі міжнародні організацій в області дослідження і використання космічного простору ООН уже не встигають акумулювати всю, як позитивну, так і негативну інформацію про космос, а фактично лише констатують їі. Тому, постає питання про створення спеціалізованої дієвої організації під егідою ООН, яка на підставі узгоджених юридично зобов'язуючих міжнародно-правових актів, повинна упорядкувати всі існуючі проблемні питання про космічні об'єкти, використання космічних природних ресурсів, так й інші питання про космос.

Питання про створення такої організації не є новим. Ще у 1969 році на VIII сесії Юридичного підкомітету Комітету ООН по космосу предметно обговорено питання про можливість і доцільність утворення міжурядової Міжнародного агентства з питань космічного простору [Каменецкая, 1980: 115-117].

Новостворена організація повинна бути об’єктивним і неупередженим арбітром щодо всіх суб'єктів космічної діяльності. У зв'язку з цим, як слушно наголошує англійський дослідник С. Хорсфорд, одним з основних принципів майбутньої діяльності такої організації є виконання своїх функцій на підставі рівного врахування інтересів всіх держав [Horsford, 1995: 201].

Отже, потреба дня вимагає як прийняття нормативно-правових актів, так створення такої дієвої організації ООН, яка є часткою більш широкого організаційного, економічного та політичного заходів, покликаних вирішити нагальні проблеми космічної діяльності.

\section{Висновки}

Будучи важливим людським ресурсом космічні об'єкти та природні ресурси повинні належати всьому людству, а не окремим державам чи/або приватним компаніям. Прийняття США та Люксембургом законодавчих актів, метою яких є легалізація, видобуток, використання та присвоєння космічних ресурсів приватними компаніями, нібито прийнято в повній відповідності з міжнародними зобов'язаннями, насправді вони порушують принципи діяльності держав по дослідженню і використанню космічного простору, включаючи Місяць та інші небесні тіла, які не підлягають національному присвоєнню ані шляхом проголошення на них суверенітету, ані шляхом використання або окупації, ані будь-якими іншими засобами (ст. II «Договір Про космос»), є однією із важливих проблем міжнародного права.

Одним із перспективних напрямків вирішення та врегулювання проблемних питань у галузі космосу є зміцнення довіри до космічної діяльності шляхом вироблення програмних документів, які автентично повинні толкуватися всіма суб'єктами міжнародного права. Зокрема, це стосується визначення нормами міжнародного права поняття «космічні об'єкти» та інших понять на які зверталася увага в резолюціях Генеральної Асамблеї ООН.

Існуюча нормативно-правова база міжнародного космічного права відстає від розвитку науково-технічного прогресу, а відповідні структури ООН - Комітет з використання космічного простору в мирних цілях і його Юридичний і Науково-технічний підкомітети не в змозі вирішити всі нагальні проблеми космічної діяльності. Варто також підкреслити, що серед значної кількості міжнародних угод, конвенцій та інших актів у сфері космічної діяльності, деякі із них і на сьогодні не підписані провідними космічними державами, що в умовах недосконалості правового регулювання космічної діяльності теж не надає можливості вирішити проблеми космічної діяльності. 
Безумовно, шлях до прийняття узгоджених нормативно-правових актів та створення відповідної організації з питань космічної діяльності не є простим і потребує вирішення низки питань організаційного, економічного, правового та політичного характеру. Вирішення нагальних проблем залежить від волі провідних держав світу, які повинні об'єднати свої зусилля на міжнародне співробітництво, заради збереження миру і безпеки. Не осторонь від цих питань повинно бути все світове наукове співтовариство, покликане спонукати держави та їх комерційні компанії до мирного дослідження космічного простору.

\section{Література}

Аннотированная предварительная повестка дня. Генеральная Ассамблея. 27 Јanuary 2017. http://www.unoosa.org/res/oosadoc/data/documents/2017/aac_105c_2l/ aac_105c_21_299_0_html/AC105_C2_L299R.pdf

Васьков, Сергей, Малков, Сергей. Нормативно-правовое обеспечение космической деятельности. Санкт-Петербург, 2003.

Галактика — наша! Які космічні об'єкти носять українські імена. EtCetera, 22.04.2018. https://uk.etcetera.media/2972-7.html

Государственные учетные системы по управлению и развитию территорий Российской Федерации (кадастры, реестры, регистры). Под ред. А.П. Сизова. Москва: КНОРУС, 2016.

Гражданский кодекс Российской Федеращии: принят Государственной Думой 21.10.1994 г. № 51-Ф3. https://www.grazkodeks.ru/

Декларация правовых принциипов, регулирующих деятельность государств по исследованию и использованию космического пространства. Принята резолюцией 1962 (XVIII) Генеральной Ассамблеи от 13 декабря 1963 года. http://www.un.org/ru/ documents/decl_conv/declarations/outerspace_principles.shtml

Закон КНР «О вещнызх правах». От 16.03.2007 г. https://chinalaw.center/civil_law/china real_rights_law_2007_russian/

Закон РФ от 20 августа $199 \overline{3}$ г. N 5663-I «О космической деятельности» (с изменениями и дополнениями). http://base.garant.ru/136323/

Інформація про діяльність міжнародних міжурядових і неурядових організацій, яка причетна до космічного права. Записка Секретарiamy ГА ООН. https://undocs.org/ ru/A/AC.105/C.2/110. Add.1 Distr.: General 30 January 2017.

Каменецкая, Елена. Космос и международные организациии: международно-правовые проблемы. Москва: Наука, 1980.

Конвенція про створення Європейського космічного агентства. Підписання від 30.05.1975. https://zakon.rada.gov.ua/laws/show/994_462

Конвенція про реєстрацію об'єктів, щзо запускаються в космічний простір. Принятие от 14.01.1975a. https://zakon.rada.gov.ua/laws/show/995_253?lang=ru

Корецький, Володимир. Вибрані праці: У 2 m. Київ: Наукова думка, 1989.

Косарев, Андрей. Римское частное право. Москва: Юриспруденция, 2007.

Люксембург разрешил частным компаниям добывать полезные ископаемые в космосе. ИИС “Металлоснабжение и сбыл”, 7 июля 2017 г. http://www.metalinfo.ru/ru/ news/95759

Определение СК по экономическим спорам Верховного Суда РФ от 07.04. 2016 г. № 310ЭС15-16638. http://base.garant.ru/71372820/ 
Про космічну діяльність: Закон України від 15.11 .1996 р. № 502/96-ВР. Відомості Верховної Ради України. 1997. № 1. Ст. 2.

Резолюиії Генеральної асамблеї Організаиії Об'єднаних Наџйй 1721(XIV) від 20.12 1961 p. https://undocs.org/ru/A/RES/1721(XVI)

Тимофеев, Виктор. США, Китай и Россия выдвигают претензии на Марс — «холодная война» может перерасти в «звездные войны». КП в Украине, 30 октября 2018.

Тягай, Екатерина. Сложноструктурные модели права собственности в США. Москва, 2011. http://www.dslib.net/civil-pravo/slozhnostrukturnye-modeli-prava-sobstvennosti-v-ssha.html

Хель, Илья. Космос открыт для бизнеса. Что будет дальше? Hi-News. ru, 31.07.2018. https://hi-news.ru/space/kosmos-otkryt-dlya-biznesa-chto-budet-dalshe.html

Шикарев, Сергей. Космонавтика подчинена интересам коммерции. Инвест-Форсайт. 08. 02. 2018. https://www.if24.ru/kosmonavtika-i-kommertsia/

Цивільний кодекс України: Закон України від 16.01.2003 p. № 435-IV. Biдомості Верховної Ради. 2003. №№ 40-44. Ст. 356.

Agreement Governing the Activities of States on the Moon and Other Celestial Bodies. Resolution 34/68, General Assembly, 05.12.1979. http://www.unoosa.org/oosa/en/ ourwork/spacelaw/treaties/intromoon-agreement.html

Horsford, C. E. S. Is I.C.A.O. the Model for an International Space Agency? International Institute of Space Law, Issue 3 1995: 199-203.

Howard, Philip K. There Is No 'Right to Sue'. Wall Street Journal. July 31, 2002.

Lefeber, René. Relaunching the Moon Agreement. Air \& Space Law. Vol. 41. №. 1, 2016: 41-48.

Lunar Embassy. 2019. https://lunarembassy.com/

Masson-Zwaan, Tanja, and Bob Richards. International Perspectives on Space Resource Rights. Space News, December 8, 2015. https://spacenews.com/op-ed-internationalperspectives-on-space-resource-rights/

Planetary resources. 2019. https://www.planetaryresources.com/

Position Paper on Space Resource Mining. International Institute of Space Law. December 20, 2015. http://www.iislweb.org/docs/SpaceResourceMining.pdf

President Donald J. Trump is Unveiling an America First National Space Strategy. March 23, 2018. https://www.whitehouse.gov/briefings-statements/president-donald-j-trumpunveiling-america-first-national-space-strategy/

Rummel, John. D. One Small Step for Space Resources. SpaceNews. December 9, 2015. https://spacenews.com/op-ed-the-next-steps-for-space-resources/

Setsuko, Aoki. New Law Aims to Expand Japan's Space Business. Nippon Communications Foundation. Mar 3, 2017.

Space Law: Development and Scope. Edited by Nandasiri Jasentuliyana. Praeger, 1992

Sundahl, Mark J., and V. Gopalakrishnan. New Perspectives on Space Law Proceedings of the 53rd IISL Colloquium on the Law of Outer Space, Young Scholars Sessions. Paris International Institute of Space Law, 2011.

Treaty on Principles Governing the Activities of States in the Exploration and Use of Outer Space, including the Moon and Other Celestial Bodies. General Assembly, resolution 2222 (XXI). 27 January 1967. http://www.unoosa.org/oosa/en/ourwork/spacelaw/ treaties/introouterspacetreaty.html 
US Commercial Space Launch Competitiveness Act. July 22, 2015, https://www.congress.gov/ congressional-report/114th-congress/senate-report/88/1

\section{References}

Annotyrovannaia predvarytelnaia povestka dnia. Heneralnaia Assambleia. 27 January 2017. http://www.unoosa.org/res/oosadoc/data/documents/2017/aac_105c_2l/ aac_105c_21_299_0_html/AC105_C2_L299R.pdf

Vaskov, Serhei, Malkov, Serhei. Normatyvno-pravovoe obespechenye kosmycheskoi deiatelnosty. Sankt-Peterburh, 2003.

Halaktyka — nasha! Yaki kosmichni obiekty nosiat ukrainski imena. EtCetera, 22.04.2018. https://uk.etcetera.media/2972-7.html

Hosudarstvennыe uchetnыe systemы po upravlenyiu y razvytyiu terrytoryi Rossyiskoi Federatsyy (kadastrы, reestrы, rehystrы). Pod red. A.P. Syzova. Moskva: KNORUS, 2016.

Hrazhdanskyi kodeks Rossyiskoi Federatsyy: pryniat Hosudarstvennoi Dumoi 21.10.1994 h. № 51-FZ. https://www.grazkodeks.ru/

Deklaratsyia pravovыkh pryntsypov, rehulyruiushchykh deiatelnost hosudarstv po yssledovanyiu y yspolzovanyiu kosmycheskoho prostranstva. Pryniata rezoliutsyei 1962 (XVIII) Heneralnoi Assambley ot 13 dekabria 1963 hoda. http://www.un.org/ru/ documents/decl_conv/declarations/outerspace_principles.shtml

Zakon KNR «O veshchnыkh pravakh». Ot 16.03.2007 h. https://chinalaw.center/civil_law/ china_real_rights_law_2007_russian/

Zakon RF ot 20 avhusta 1993 h. N 5663-I «O kosmycheskoi deiatelnosty» (s yzmenenyiamy y dopolnenyiamy). http://base.garant.ru/136323/

Informatsiia pro diialnist mizhnarodnykh mizhuriadovykh i neuriadovykh orhanizatsii, yaka prychetna do kosmichnoho prava. Zapyska Sekretariatu HA OON. https:/undocs.org/ ru/A/AC.105/C.2/110. Add.1 Distr.: General 30 January 2017.

Kamenetskaia, Elena. Kosmos y mezhdunarodnыe orhanyzatsyy: mezhdunarodno-pravovыe problemы. Moskva: Nauka, 1980.

Konventsiia pro stvorennia Yevropeiskoho kosmichnoho ahentstva. Pidpysannia vid 30.05.1975. https://zakon.rada.gov.ua/laws/show/994_462

Konventsiia pro reiestratsiiu obiektiv, shcho zapuskaiutsia v kosmichnyi prostir. Pryniatye ot 14.01.1975a. https://zakon.rada.gov.ua/laws/show/995 253?lang=ru

Koretskyi, Volodymyr. Vybrani pratsi: U 2 t. Kyiv: Naukova dumka, 1989.

Kosarev, Andrei. Rymskoe chastnoe pravo. Moskva: Yurysprudentsyia, 2007.

Liuksemburh razreshyl chastnыm kompanyiam dobыvat poleznыe yskopaemыe v kosmose. YYS "Metallosnabzhenye y sbыt", 7 yiulia 2017 h. http://www.metalinfo.ru/ru/ news/95759

Opredelenye SK po эkonomycheskym sporam Verkhovnoho Suda RF ot 07.04. 2016 h. № 310-ЭS15-16638. http://base.garant.ru/71372820/

Pro kosmichnu diialnist: Zakon Ukrainy vid 15.11.1996 r. № 502/96-VR. Vidomosti Verkhovnoi Rady Ukrainy. 1997. № 1. St. 2.

Rezoliutsii Heneralnoi asamblei Orhanizatsii Obiednanykh Natsii 1721(XIV) vid $20.121961 \mathrm{r}$. https://undocs.org/ru/A/RES/1721(XVI) 
Tymofeev, Vyktor. SShA, Kytai y Rossyia vыdvyhaiut pretenzyy na Mars — "kholodnaia voina” mozhet pererasty v "zvezdnыe voinы”. KP v Ukrayne, 30 oktiabria 2018.

Tiahai, Ekateryna. Slozhnostrukturnыe modely prava sobstvennosty v SShA. Moskva, 2011. http://www.dslib.net/civil-pravo/slozhnostrukturnye-modeli-prava-sobstvennosti-vssha.html

Khel, Ylia. Kosmos otkrыt dlia byznesa. Chto budet dalshe? Hi-News. ru, 31.07.2018. https:// hi-news.ru/space/kosmos-otkryt-dlya-biznesa-chto-budet-dalshe.html

Shykarev, Serhei. Kosmonavtyka podchynena ynteresam kommertsyy. Ynvest-Forsait. 08. 02. 2018. https://www.if24.ru/kosmonavtika-i-kommertsia/

Tsyvilnyi kodeks Ukrainy: Zakon Ukrainy vid 16.01.2003 r. № 435-IV. Vidomosti Verkhovnoi Rady. 2003. №o 40-44. St. 356.

Agreement Governing the Activities of States on the Moon and Other Celestial Bodies. Resolution 34/68, General Assembly, 05.12.1979. http://www.unoosa.org/oosa/en/ ourwork/spacelaw/treaties/intromoon-agreement.html

Horsford, C. E. S. Is I.C.A.O. the Model for an International Space Agency? International Institute of Space Law, Issue 3 1995: 199-203.

Howard, Philip K. There Is No 'Right to Sue'. Wall Street Journal. July 31, 2002.

Lefeber, René. Relaunching the Moon Agreement. Air \& Space Law. Vol. 41. №. 1, 2016: 41-48.

Lunar Embassy. 2019. https://lunarembassy.com/

Masson-Zwaan, Tanja, and Bob Richards. International Perspectives on Space Resource Rights. Space News, December 8, 2015. https://spacenews.com/op-ed-internationalperspectives-on-space-resource-rights/

Planetary resources. 2019. https://www.planetaryresources.com/

Position Paper on Space Resource Mining. International Institute of Space Law. December 20, 2015. http://www.iislweb.org/docs/SpaceResourceMining.pdf

President Donald J. Trump is Unveiling an America First National Space Strategy. March 23, 2018. https://www.whitehouse.gov/briefings-statements/president-donald-j-trumpunveiling-america-first-national-space-strategy/

Rummel, John. D. One Small Step for Space Resources. SpaceNews. December 9, 2015. https://spacenews.com/op-ed-the-next-steps-for-space-resources/

Setsuko, Aoki. New Law Aims to Expand Japan's Space Business. Nippon Communications Foundation. Mar 3, 2017.

Space Law: Development and Scope. Edited by Nandasiri Jasentuliyana. Praeger, 1992

Sundahl, Mark J., and V. Gopalakrishnan. New Perspectives on Space Law Proceedings of the 53rd IISL Colloquium on the Law of Outer Space, Young Scholars Sessions. Paris International Institute of Space Law, 2011.

Treaty on Principles Governing the Activities of States in the Exploration and Use of Outer Space, including the Moon and Other Celestial Bodies. General Assembly, resolution 2222 (XXI). 27 January 1967. http://www.unoosa.org/oosa/en/ourwork/spacelaw/ treaties/introouterspacetreaty.html

US Commercial Space Launch Competitiveness Act. July 22, 2015, https:/www.congress.gov/ congressional-report/114th-congress/senate-report/88/1 